\title{
Two Cases of Intracranial Hypotension with Low-tone Hearing Loss
}

\author{
Yumiko Hikida ${ }^{12)}$, Atsuro Seki ${ }^{1)}$ and Hiroyuki Mineta ${ }^{2)}$
}

We report two cases of intracranial hypotension. In one case, MRI showed typical findings, including diffuse thickening, enhancement of the dura mater, and pseudocyst at the level of $\mathrm{C} 6$ and 7 resulting from the leakage of CSF. In the other case, treatment with an epidural blood patch (EBP) improved his symptom, almost completely, although no typical findings were pointed out in MRI. The patient presented with bilateral mild hearing loss and abnormal eye movements before the application of the EBP, while the symptoms disappeared after the EBP application. Not all cases show typical findings, therefore, obtaining a proper history, including of any head injury, is important for the diagnosis of intracranial hypotension.

Keywords : intracranial hypotension, hearing loss, headache

\section{References}

1）脳脊髄液減少症研究会ガイドライン作成委員会: 脳脊髄液 減少症ガイドライン 2007. 15-18 頁, メディカルレビュー 社, 大阪, 2007.

2）中島成人：特発性低髄液圧症候群に伴った両側急性低音障 害型感音難聴の 1 例. Audiol Jpn 45: 187-191, 2002.

3) Arai M, Takada T and Nozue M : Orthostatic tinnitus: an otological presentation of spontaneous intracranial hypotension. Auris Nasus Larynx 30: 85-87, 2003.

4）松村道哉, 千田英二, 柏村正明, 他 : 低音障害型感音難聴 とめまいを呈した特発性低髄液圧症候群の 1 例. 耳鼻・頭 頸外科 75: 735-738, 2003.

5) Miller RS, Tami TA and Pensak M : Spontaneous intracranial hypotension mimicking Menière's disease. Otolaryngol Head and Neck Surg 135: 655-656, 2006.

6) Taki M, Nin F, Hasegawa T, et al. : Case report: two cases of hearing impairment due to intracranial hypotension. Auris Nasus Larynx 36: 345-348, 2009.

7) Isildak $\mathrm{H}$, Albayram $\mathrm{S}$ and Isildak $\mathrm{H}$ : Spontaneous intracranial hypotension syndrome accompanied by bilateral hearing loss and venous engorgement in the internal acoustic canal and positional change of audiography. J Craniofac Surg 21: 165167, 2010.

8) Chen S, Hagiwara M and Roehm PC : Spontaneous intracranial hypotention presenting with severe sensorineural hearing loss and headache. Otol Neurotol 33: e65-e66, 2012.

9）脳脊髄液減少症研究会: 第 4 回脳脊髄液減少症研究会. 脑 脊髄液減少症データ集 Vol. 1一研究会全抄録と最新発表 報告一（篠永正道, 美馬達夫監).72-73 頁, メディカルレ ビュー社, 2007.

10）喜多村孝幸：脳脊髄液減少症（低骾液圧症候群）. Annual Review 神経 2006. 172-177 頁, 中外医学社, 東京, 2006.

11）吉本智信 : 低髄液圧症候群に関する報道の変遷. 低骾液圧 症候群一ブラッドパッチを受けた人, または, これから受 ける人へ 精神医学と賠償シリーズ(3). 168-170 頁, 自動 車保険ジャーナル，東京， 2006.

12）吾郷哲朗, 藤島正敏: 特発性低䯣液圧症候群の症候と診断. 神経内科 53: 434-438, 2000 .
1) Department of Otolaryngology, JA Shizuoka Kohseiren Enshu Hospital

2) Department of Otorhinolaryngology/Head \& Neck Surgery, Hamamatsu University School of Medicine
Corresponding Author Address : Yumiko Hikida a04063hikida@yahoo.co.jp 